Original Research

\title{
Effects of Iron-Modified Biochar and AMF Inoculation on the Growth and Heavy Metal Uptake of Senna occidentalis in Heavy Metal-Contaminated Soil
}

\author{
Xiongfei Guo ${ }^{1,2}$, Huashou $\mathrm{Li}^{2 *}$ \\ ${ }^{1}$ Chemical Synthesis and Pollution Control Key Laboratory of Sichuan Province, College of Environmental Science \\ and Engineering, China West Normal University, Nanchong, Sichuan, P.R. China \\ ${ }^{2}$ College of Resources and Environmental Sciences, South China Agricultural University, \\ Guangzhou, P.R. China
}

Received: 18 April 2018

Accepted: 24 June 2018

\begin{abstract}
S. occidentalis can be used in pharmacology and vegetation restoration. A pot experiment was conducted to study the effects of biochar and mycorrhizal fungus inoculation on plant growth and heavy metal accumulation. The mycorrhizal infection rate was increased by apple branch biochar but decreased by coconut husk iron-modified biochar. Conversely, soil pH was not affected by mycorrhizal inoculation but was increased by biochar. Compared to the uninoculated control, the combination of apple branch biochar and mycorrhizal inoculation significantly increased the growth of stems, leaves and roots by $226.46 \%, 163.15 \%$ and $86.00 \%$, respectively. The application of apple branch biochar increased the root $\mathrm{Pb}$ content, while root $\mathrm{Cd}, \mathrm{Cr}, \mathrm{Cu}$ and $\mathrm{Fe}$ were decreased by $36.30 \%, 13.63 \%, 3.09 \%$ and $7.66 \%$, respectively. Furthermore, the content of all elements in the stems and leaves also decreased. The application of iron-modified biochar alone increased the content of all the elements in the roots by $4.23-109.33 \%$. But their contents in stems and leaves were decreased by iron-modified biochar and mycorrhizal inoculation alone. The combination of biochar and mycorrhizal inoculation most effectively promoted plant growth, enhanced heavy metal uptake by the roots and produced a barrier effect that reduced the transfer of heavy metals from the roots to the shoots. This might constitute a feasible means of promoting the safe utilization of $\mathrm{S}$. occidentalis in phytoremediation.
\end{abstract}

Keywords: S. occidentalis; iron-modified biochar; heavy metal; arbuscular mycorrhizal (AM) fungi

*e-mail: 764172280@qq.com 


\section{Introduction}

Arbuscular mycorrhizal fungi (AMF) are able to form a symbiosis with the vast majority of higher plants [1]. Existing in both common farmland soil and in the soils of hostile environments, AMF can improve the stress resistance and mineral nutrition (especially P) of host plants, and can be used to improve plant growth and health [2]. In addition, in heavy metal-contaminated soil, AMF can affect the heavy metal transformation processes in the soil-plant system via several ways, thus affecting the uptake and accumulation of heavy metals and reducing their toxicity to plants. Biochar is a carbonaceous product obtained via the pyrolysis of organic materials. As a soil amendment, biochar can also increase soil organic matter, improve soil fertility, increase crop yields and reduce pollution by heavy metals and pesticides in soil [3-5]. The addition of biochar can increase the availability of soil nutrients by influencing the physical and chemical characteristics of the soil [6], which may lead to high AMF colonization rates in plant roots as well as an enhancement of the performance of the host plant, including increases in the nutrient concentration of plant tissues [7]. Biochar can also provide shelter for AM fungi to deter predation of the hyphae, which is beneficial for the growth of the mycelium. The adsorption capacity of biochar is associated with its physical and chemical properties, which can be improved by modification. The loading of ferric salts is a common modification method [8]. The iron oxide and hydroxyl oxide can load on the surface of modified biochar, and following iron modification, the adsorption ability of biochar to heavy metals may be enhanced. For instance, an improvement in soybean growth was observed following iron modification in one experiment [9]. Therefore, the promotion of nutrient absorption in plants and the reduction of heavy metal pollution risk in contaminated soil might be synergistically associated with the addition of biochar and inoculation with AMF. This has rarely been reported.

Senna occidentalis (Caesalpinioideae: Fabaceae), formerly Cassia occidentalis and commonly known as "kasondi" or "coffeeweed," is a widely distributed pantropical suffrutescent herb. We chose this plant as our research material as it possesses a variety of medical uses with great pharmacological potential, and thus has high economic value [10]. It can thrive in low P soil and commonly occurs in heavy metal-contaminated areas [11]. Not only is $S$. occidentalis a medicinal herb, but the above characteristics indicate that it is able to thrive even under adverse environmental conditions, and has potential application as a restorative material in heavy metal-contaminated areas. However, there is little experimental research regarding the application of biochar and AMF in the cultivation of $S$. occidentalis, as well as in heavy metal risk management. We hypothesized that biochar application and AMF inoculation might have a synergist promoting effect on the growth of $S$. occidentalis and in the alleviation of heavy metal pollution. A pot experiment was thus performed to investigate the effects of standard biochar, iron-modified biochar and AMF on growth and heavy metal accumulation in $S$. occidentalis in heavy metal-contaminated soil, with the aim of providing technical support for the safe utilization of $S$. occidentalis in the restoration of contaminated areas.

\section{Materials and Methods}

\section{Supplied Experimental Plants}

Senna occidentalis seeds were collected from an ecological farm at the South China Agricultural University $\left(23^{\circ} 10^{\prime} \mathrm{N}, \quad 113^{\circ} 22^{\prime} \mathrm{E}\right)$. After surface sterilization with $10 \%$ hydrogen peroxide for $10 \mathrm{~min}$, the seeds were flushed with deionized water and spread in a tray covered with wet absorbent paper. Following germination at $28^{\circ} \mathrm{C}$ for $2 \mathrm{~d}$, the germinated seeds were sown in the test pots.

\section{Mycorrhizal Fungi and Biochar}

The AM fungus prepared for this experiment was Glomus mosseae (Glomeraceae) and the strains were purchased from the Institute of Plant Nutrition and Resources (Beijing Academy of Agriculture and Forestry Sciences). The test microbial agents were obtained through the propagation of potted maize and the inoculants constituted mixtures of the spores containing mycorrhizal fungi, the roots of the host plant and the culture medium. One gram of inoculants contained approximately 50 spores.

Two types of biochar were used for the experiment and were marked as $\mathrm{BC}$ (standard) and $\mathrm{Fe}-\mathrm{BC}$ (iron-modified); the former was produced from apple branches while the latter was produced from coconut husks.

The BC was provided by the Shaanxi Yixin Biological Energy Science and Technology Development Limited Liability Company, Xi'an, China. The production steps were as follows: apple tree branches were chopped into small pieces, dried at $80^{\circ} \mathrm{C}$ and then pyrolized at $550^{\circ} \mathrm{C}$ for 2 to $8 \mathrm{~h}$ following a preheat treatment in a kettle that had been filled with nitrogen.

The Fe-BC was provided by the Guangdong Institute of Eco-Environment and Soil Sciences. The preparation process included (1) biochar material preparation: the biomass (coconut husk) was dried, crushed and heated up to 300 to $800^{\circ} \mathrm{C}$ for $3-12 \mathrm{~h}$ following a preheat treatment; (2) iron and biochar mixture preparation: iron was added to the biochar materials prepared in the previous step. The iron and biochar mixture was obtained after stirring and the mass percentage of biochar and iron was 15:1; (3) biochar material activation: the reducing agent solution with a mass percentage of $0.01 \sim 10 \%$ was added to the prepared 
Table 1. Physicochemical properties of the test soil and biochars used in the experiment.

\begin{tabular}{|c|c|c|c|c|c|c|c|c|c|}
\hline Parameter & $\begin{array}{c}\mathrm{pH} \\
\left(\mathrm{H}_{2} \mathrm{O}\right)\end{array}$ & $\begin{array}{c}\text { Total C } \\
\left(\mathrm{g} \mathrm{kg}^{-1}\right)\end{array}$ & $\begin{array}{c}\text { Total N } \\
\left(\mathrm{g} \mathrm{kg}^{-1}\right)\end{array}$ & $\begin{array}{c}\text { Total P } \\
\left(\mathrm{g} \mathrm{kg}^{-1}\right)\end{array}$ & $\begin{array}{c}\text { Total Cd } \\
\left(\mathrm{mg} \mathrm{kg}^{-1}\right)\end{array}$ & $\begin{array}{c}\text { Total Cr } \\
\left(\mathrm{mg} \mathrm{kg}^{-1}\right)\end{array}$ & $\begin{array}{c}\text { Total Cu } \\
\left(\mathrm{mg} \mathrm{kg}^{-1}\right)\end{array}$ & $\begin{array}{c}\text { Total Fe } \\
\left(\mathrm{mg} \mathrm{kg}^{-1}\right)\end{array}$ & $\begin{array}{c}\text { Total Pb } \\
\left(\mathrm{mg} \mathrm{kg}^{-1}\right)\end{array}$ \\
\hline Substrates & 5.50 & 3.42 & 1.063 & 0.04 & 3.31 & 23.80 & 1354.49 & 12457.86 & 457.92 \\
\hline BC & 9.82 & 678.76 & 20.21 & 2.21 & $/$ & $/$ & 12.90 & 201.45 & $/$ \\
\hline Fe-BC & 9.40 & 587.21 & 16.56 & 2.80 & $/$ & $/$ & 13.67 & 231.09 & $/$ \\
\hline
\end{tabular}

mixture in the previous step and stirred for 2 to $6 \mathrm{~h}$ in preparation for the next step; (4) iron-modified biochar material preparation: emulsifier solution was added to the activated materials prepared in step (3) and the iron base carbon material was obtained after stirring at 300 to $800^{\circ} \mathrm{C}$ for $2 \sim 6 \mathrm{~h}$, followed by cooling, drying and eventually crushing. The selected properties are presented in Table 1.

\section{Test Substance}

The culture substrates included mixtures of mining area soil and woodland surface soil mixed at a mass ratio of 4:1 (dry weight). Unless otherwise specified, the "soil" in the following sections refers to all the mixed culture substrates. The mine soils and the woodland surface soils were obtained from the Dabaoshan mine in Shaoguan City, Guangdong $\left(24^{\circ} 34^{\prime} \mathrm{N}, 113^{\circ} 43^{\prime} \mathrm{E}\right)$ and the ecological farm of South China Agricultural University $\left(23^{\circ} 10^{\prime} \mathrm{N}, 113^{\circ} 22^{\prime} \mathrm{E}\right)$. Some of their basic properties are indicated in Table 1. The mixed soils for the experiment were sterilized using high-pressure steam for $2 \mathrm{~h}$ at $121^{\circ} \mathrm{C}$ to eliminate the indigenous AM fungi. After the digestion of soil with aqua regia and perchloric acid, the heavy metals were measured using inductively coupled plasma optical emission spectroscopy (ICP-OES[Optima 5300DV, Perkin-Elmer Instruments, USA]). The contents are listed in Table 1.

\section{Experimental Design}

The experimental design contained 6 treatments in total. There were 3 treatments under each category of inoculated $(+\mathrm{M})$ and non-inoculated (-M): (1) non-application of biochar (CK); (2) application of standard apple branch biochar (BC); and (3) application of iron-modified coconut husk biochar (Fe-BC), with 4 repeats in a randomized block arrangement.

Each round plastic pot $(18 \mathrm{~cm}$ upper diameter, $12 \mathrm{~cm}$ lower diameter, $13 \mathrm{~cm}$ depth) contained $2 \mathrm{~kg}$ of the sterilized soil, which was mixed with $80 \mathrm{~g}$ of fungal inoculant for each $+\mathrm{M}$ pot. The same amount of fungal inoculant was sterilized with a high pressure steam for $2 \mathrm{~h}$ at $121^{\circ} \mathrm{C}$ to eliminate the indigenous AM fungi for each -M pot. Additionally, $80 \mathrm{~g}$ of biochar was applied accordingly.

Six S. occidentalis seeds were sowed into each pot. Five days after germination, 2 seedings indicating similar growth were retained in each pot. During the experiment, plants were maintained under natural light and were watered by hand, ensuring that the soil water content was $60 \%$ of the maximum field capacity.

\section{Sampling and Plant Analysis}

Following 12 weeks of growth, the seedlings were harvested and separated from the soil surface. The shoot and root parts of the plants were carefully cleaned with deionized water. About $0.5 \mathrm{~g}$ of fresh root was used for determining mycorrhizal infection rate. The rest of the plant samples were weighed after oven drying at $70^{\circ} \mathrm{C}$ for $48 \mathrm{~h}$ to achieve constant weight, after which the dry weight of each part was calculated. The mycorrhizal colonization status was observed by using staining microscopic examination [12], and the mycorrhizal infection rate was calculated using the method of Biermann et al. [13]. The plant samples were dried, ground, sieved through a $0.5 \mathrm{~mm}$ sieve and digested with $\mathrm{H}_{2} \mathrm{SO}_{4}-\mathrm{H}_{2} \mathrm{O}_{2}$.

The $\mathrm{P}$ content was determined using the $\mathrm{Mo}-\mathrm{Sb}$ colorimetric method. A certain weight of the plant sample was digested with high-purity $\mathrm{HNO}_{3}$ at $160^{\circ} \mathrm{C}$ and the determination of $\mathrm{Cd}, \mathrm{Cr}, \mathrm{Cu}, \mathrm{Fe}$ and $\mathrm{Pb}$ was performed using (ICP-OES[Optima 5300DV, PerkinElmer Instruments, USA]).

$\mathrm{HCl}$-extractable concentrations of heavy metals in soils were measured using an acid extraction method [14]. Calibration accuracy was measured concurrently using reference materials.

The ability of the plant to translocate metals from roots to stems and leaves was assessed using the translocation factor $(\mathrm{TF}=$ metal concentration in the stems and leaves/metal concentration in the roots).

\section{Statistical Analysis}

One-way ANOVA was employed using Microsoft Excel 2010 and SPSS 19.0 (IBM Corp). The differences between treatments were compared with Duncan multiple comparisons $(p<0.05)$.

\section{Results}

\section{Mycorrhizal Root Colonization}

Root colonization was not observed in the uninoculated mycorrhizal groups. As indicated in Fig. 1, 


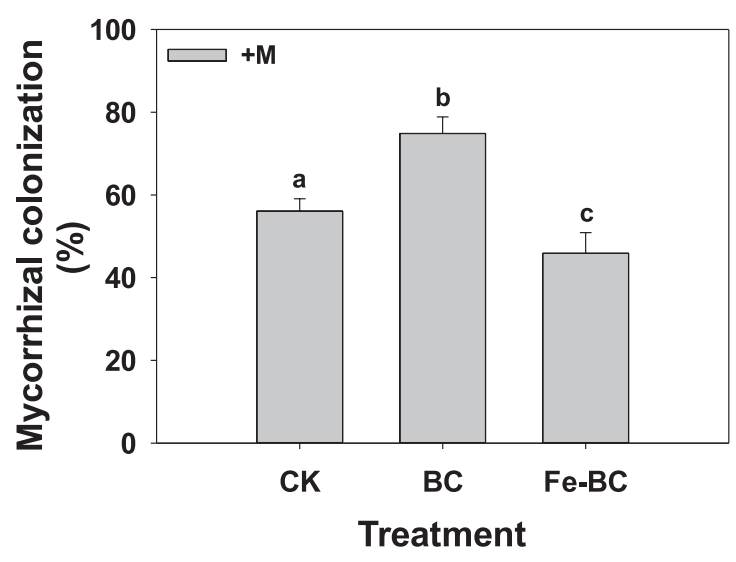

Fig. 1. Mycorrhizal colonization rates of Senna occidentalis under different treatments.

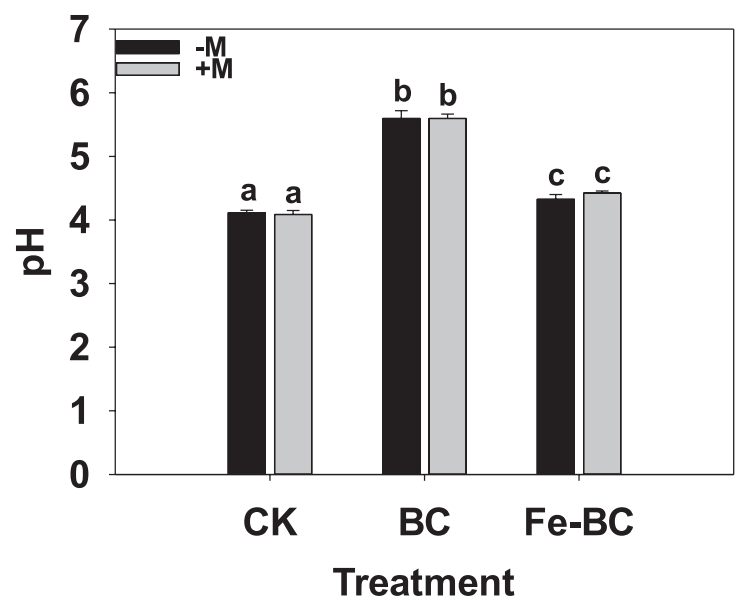

Fig. 2. Influence of biochars and AMF on soil pH. inoculation with AM fungi resulted in a high infection rate in the roots of $S$. occidentalis. Compared with the control groups that received only a single inoculation of AM fungi, the addition of standard biochar significantly increased the mycorrhizal colonization rate $(p<0.05)$, while the iron-modified biochar decreased the mycorrhizal infection rate $(p<0.05)$.

\section{Soil pH}

Compared with the control treatments lacking biochar (CK), soil $\mathrm{pH}$ increased significantly $(p<0.05)$ with biochar application. Moreover, standard biochar was more effective than the iron-modified biochar in increasing soil $\mathrm{pH}$. Irrespective of biochar application, soil $\mathrm{pH}$ was not affected significantly by the addition of AMF (Fig. 2). The effects of biochar and AMF inoculation on soil $\mathrm{pH}$ were therefore not interactive.

\section{Biomass and P Concentration of S. occidentalis}

As shown in Fig. 3, AMF inoculation alone had no obvious influence on root dry weight in the CK group in the absence of $\mathrm{BC}$. Under the application of $\mathrm{BC}$ and $\mathrm{Fe}-\mathrm{BC}$, AMF inoculation significantly increased the dry weight of the leaves, stems and roots by more than $59.36 \%$ compared with the uninoculated samples. In the absence of AMF inoculation, the application of the 2 types of biochar decreased the dry weight of the leaves, stems and roots and, compared to the standard $\mathrm{BC}$, the declines in root dry weight as a result of iron-modified $\mathrm{BC}$ application were greater, while the decreasing amplitude of shoot dry weight was smaller. Under the conditions of AMF inoculation, the influence
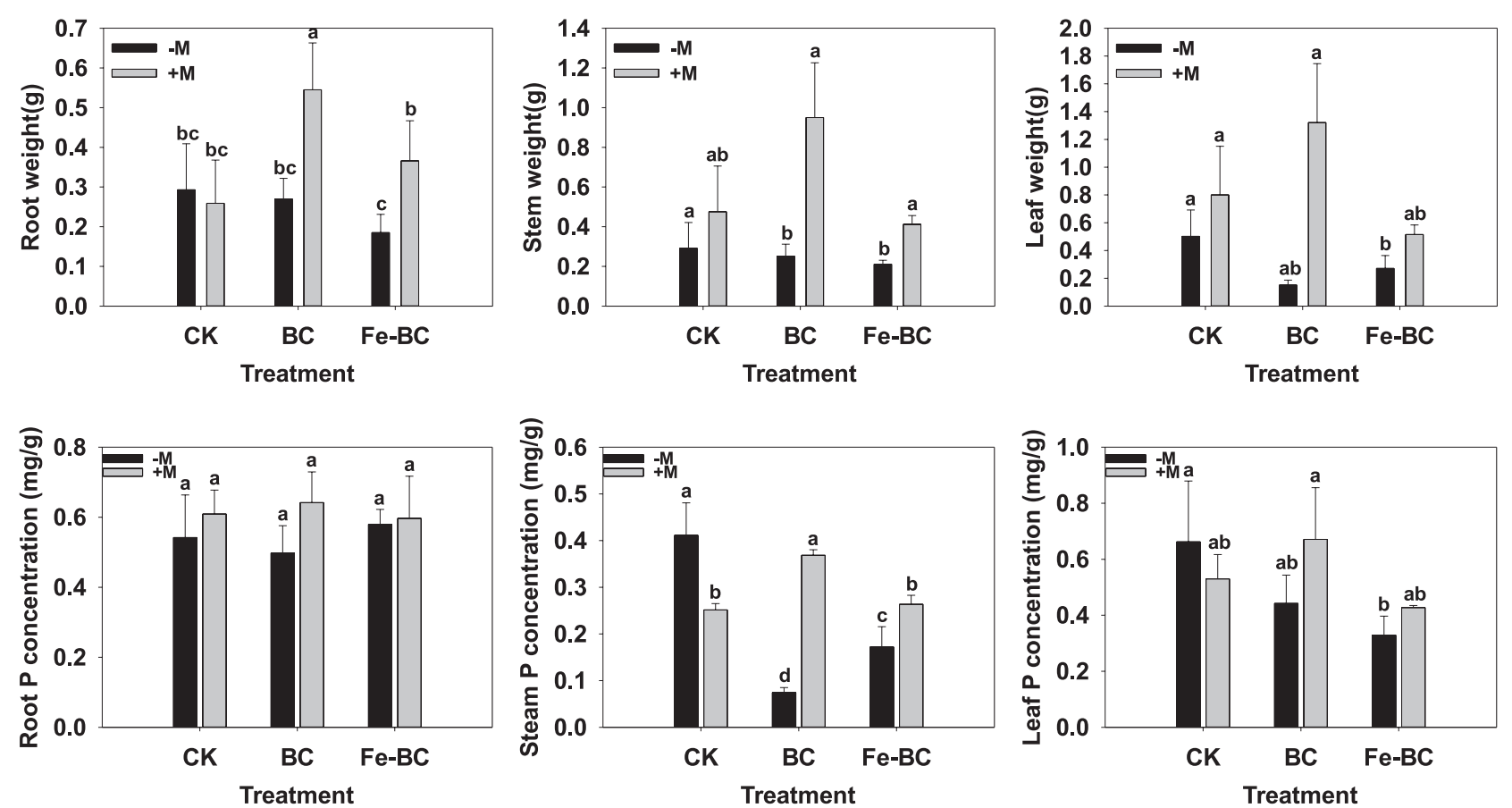

Fig. 3. Plant dry weights (top row) and P concentrations (next row) under different experimental treatments. 
of the 2 types of $\mathrm{BC}$ on dry weight of the stems, leaves and roots differed. The application of standard BC increased the dry weight of the stems, leaves and roots. Conversely, the application of iron-modified $\mathrm{BC}$ reduced the dry weight of the stems, leaves and shoots, but increased root dry weight. Compared with (CK [-M]), the combination of standard $\mathrm{BC}$ and $\mathrm{AMF}$ inoculation increased the biomass of the stems, leaves and shoots by $226.46 \%, 163.15 \%$ and $86 \%$, respectively, while the combination of iron-modified $\mathrm{BC}$ and $\mathrm{AMF}$ inoculation increased the biomass of the stems, leaves and shoots by $41.58 \%, 2.59 \%$ and $24.91 \%$, respectively. Thus, the combination of standard $\mathrm{BC}$ application and $\mathrm{AMF}$ inoculation was most effective at increasing the dry weight of the stems, leaves and roots.

Fig. 3 indicates that the application of biochar alone had no significant effect on root $\mathrm{P}$ concentration. Compared with $-\mathrm{M}$, mycorrhizal inoculation increased the root $\mathrm{P}$ concentration by $2.98-29.00 \%$ in the different biochar treatments. The application of biochar alone reduced the $\mathrm{P}$ concentration of stems and leaves by $58.19-81.95 \%$ and $33.24-50.34 \%$, respectively. Mycorrhizal inoculation alone reduced the $\mathrm{P}$ concentration of the stems and leaves by $38.86 \%$ and $20 \%$, respectively. However, the combination of biochar and mycorrhizal inoculation significantly increased the $\mathrm{P}$ concentration of the stems and leaves. Compared with CK (uninoculated samples), the combination of standard $\mathrm{BC}$ and mycorrhizal inoculation increased the $\mathrm{P}$ concentration of the stems and leaves by $396.77 \%$ and $51.76 \%$, respectively, while the combination of iron-modified $\mathrm{BC}$ and mycorrhizal inoculation increased the $\mathrm{P}$ concentration by $53.23 \%$ and $29.89 \%$, respectively. The combination of standard $\mathrm{BC}$ and mycorrhizal inoculation was most effective at increasing $\mathrm{P}$ concentration in the stems and leaves.

\section{HCl-Extractable Heavy Metal Concentrations}

Fig. 4 indicates that both AMF inoculation and standard $\mathrm{BC}$ had no significant effect on the $\mathrm{HCl}$ extractable $\mathrm{Cd}$ content in the soil. Regardless of AMF inoculation, the application of iron-modified $\mathrm{BC}$ increased the $\mathrm{HCl}$-extractable $\mathrm{Cd}$ content, but not significantly so $(P>0.05)$. In the absence of AMF inoculation, the application of standard $\mathrm{BC}$ alone reduced $\mathrm{HCl}$-extractable $\mathrm{Cu}$ and $\mathrm{Pb}$ by $7.12 \%$ and $49.31 \%$, respectively, and increased $\mathrm{HCl}$-extractable $\mathrm{Cr}$ by $77.39 \%$ in comparison to the control (CK). There was no significant effect on $\mathrm{HCl}$-extractable Fe. The application of iron-modified BC alone increased $\mathrm{HCl}$-extractable $\mathrm{Cu}, \mathrm{Cr}$ and $\mathrm{Fe}$ by $37.35 \%, 59.52 \%$ and $4.68 \%$, and decreased $\mathrm{HCl}$-extractable $\mathrm{Pb}$ by $25.38 \%$. Interestingly, compared with (CK [-M]), the combination of mycorrhizal inoculation with standard $\mathrm{BC}$ and iron-modified biochar increased $\mathrm{HCl}$-extractable $\mathrm{Cu}$ by $44.00 \%$ and $64.06 \%$, $\mathrm{Cr}$ by $12.11 \%$ and $7.46 \%, \mathrm{Fe}$ by $13.43 \%$ and $4 \%$ and decreased $\mathrm{HCl}$-extractable $\mathrm{Pb}$ by $67.67 \%$ and $25.21 \%$, respectively.

$\mathrm{AMF}$ inoculation alone (CK $[+\mathrm{M}])$ had no significant effect on $\mathrm{HCl}$-extractable $\mathrm{Fe}$ and $\mathrm{Cd}$, but decreased $\mathrm{HCl}$-extractable $\mathrm{Cu}$ and $\mathrm{Pb}$ by $15.45 \%$ and $13.37 \%$, respectively, and increased $\mathrm{HCl}$-extractable Cr by $46.33 \%$. With the application of standard BC, AMF inoculation decreased $\mathrm{HCl}$-extractable $\mathrm{Cr}$ and $\mathrm{Pb}$ by $7.52 \%$ and $46.08 \%$, respectively, and increased
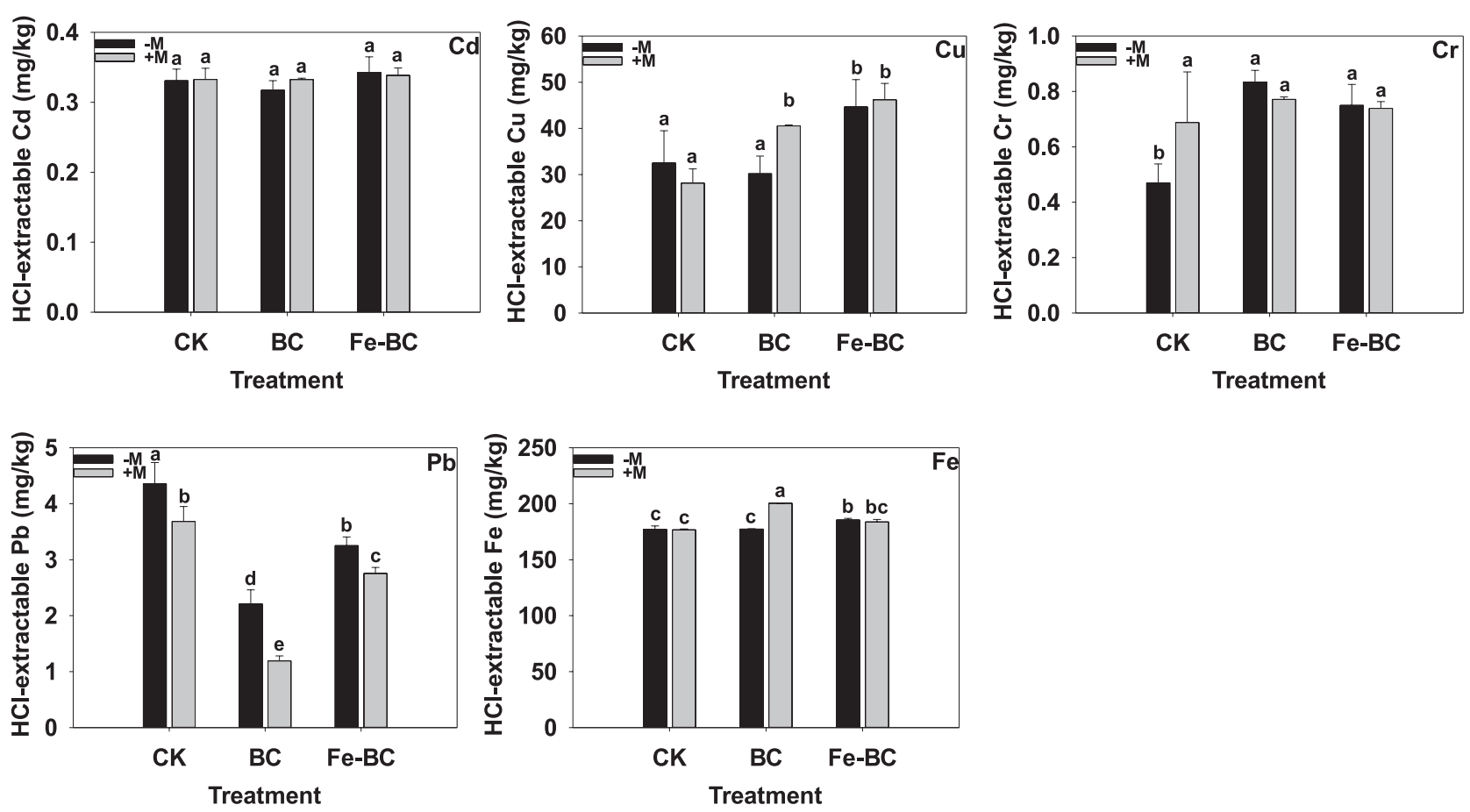

Fig. 4. HCl-extractable heavy metal concentrations in soil under different experimental treatments. 
$\mathrm{HCl}$-extractable $\mathrm{Cu}$ and $\mathrm{Fe}$ by $34.32 \%$ and $13.03 \%$, respectively, in comparison with $(\mathrm{CK}[+\mathrm{M}])$. With the application of iron-modified $\mathrm{BC}, \mathrm{AMF}$ inoculation decreased $\mathrm{HCl}$-extractable $\mathrm{Pb}$ by $15.26 \%$, but had no significant effect on the other $\mathrm{HCl}$-extractable element contents.

\section{Effects of Biochar and AMF on Plant Uptake and Translocation Factor of Heavy Metals}

As shown in Table 2, in the absence of AMF inoculation there were great differences in the effects of the 2 types of $\mathrm{BC}$ on heavy metal absorption in the roots. Compared with the control, the application of standard $\mathrm{BC}$ alone increased the $\mathrm{Pb}$ content in the roots by $102.48 \%$, and decreased $\mathrm{Cd}, \mathrm{Cr}, \mathrm{Cu}$ and $\mathrm{Fe}$ contents by $36.30 \%, 13.63 \%, 3.09 \%$ and $7.66 \%$, respectively. However, the application of iron-modified $\mathrm{BC}$ alone increased all the element contents in the roots by 4.23-109.33\%. In comparison to AMF inoculation alone, the combination of AMF inoculation with standard $\mathrm{BC}$ and iron-modified $\mathrm{BC}$ reduced $\mathrm{Cd}$ contents in the roots by $31.65 \%$ and $11.65 \%$, respectively, and increased the contents of other elements $(\mathrm{Cr}, \mathrm{Cu}, \mathrm{Fe}$ and $\mathrm{Pb})$ by $9.05-92.65 \%$ and $7.03-85.32 \%$, respectively. The iron-modified $\mathrm{BC}$ was more favorable for increasing the $\mathrm{Cu}$ and $\mathrm{Fe}$ contents, while the standard $\mathrm{BC}$ was more conducive to increasing the $\mathrm{Cr}$ and $\mathrm{Pb}$ contents in the roots. Both reduced $\mathrm{Cd}$ content in the roots, but the efficiency of the standard $\mathrm{BC}$ was higher.

The contents of $\mathrm{Cr}, \mathrm{Cu}, \mathrm{Fe}$ and $\mathrm{Pb}$, but not $\mathrm{Cd}$, in the roots decreased by $13.63 \%, 7.12 \%, 24.95 \%$ and $2.26 \%$, respectively, when only AMF inoculation was applied. With the application of standard BC, AMF inoculation slightly decreased the $\mathrm{Pb}$ content in the roots, but increased the content of all the other elements compared to the uninoculated samples. The effects of the combination of iron-modified $\mathrm{BC}$ and $\mathrm{AMF}$ inoculation on heavy metal contents were different.

With the exception that standard $\mathrm{BC}$ in combination with $\mathrm{AMF}$ inoculation slightly increased the $\mathrm{Cr}$ content in the stems in comparison to the control (CK), both types of biochar decreased the concentration of all other elements in the stems. However, in the absence of inoculation, the reduction efficiency of standard $\mathrm{BC}$ was higher than that of iron-modified $\mathrm{BC}$, specifically for $\mathrm{Cd}$ and $\mathrm{Cu}$. However, the reduction of $\mathrm{Fe}$ was lower than that of the iron-modified BC. Regardless of biochar treatment, AMF inoculation reduced the concentration of all elements in the stems.

Regarding AMF inoculation, the 2 types of biochar both increased $\mathrm{Cr}$ and $\mathrm{Pb}$ content, but decreased $\mathrm{Cd}, \mathrm{Cu}$ and $\mathrm{Fe}$ contents in the leaves in comparison with the control (CK). A single treatment of standard $\mathrm{BC}$ and iron-modified $\mathrm{BC}$ reduced $\mathrm{Cd}$ by $0.39 \%$ and $22.71 \%$ respectively, $\mathrm{Cu}$ by $17.22 \%$ and $22.63 \%$, respectively,

Table 2. $\mathrm{Cd}, \mathrm{Cr}, \mathrm{Cu}, \mathrm{Fe}$ and $\mathrm{Pb}$ concentrations $\left(\mathrm{mg} \mathrm{kg}^{-1}\right)$ in stems, leaves and roots of Senna occidentalis.

\begin{tabular}{|c|c|c|c|c|c|c|c|}
\hline \multirow{2}{*}{\multicolumn{2}{|c|}{ Biochar addition }} & \multirow{3}{*}{$\begin{array}{c}\begin{array}{c}\text { Inoculation } \\
\text { treatment }\end{array} \\
-\mathrm{M}\end{array}$} & \multicolumn{5}{|c|}{ Heavy metal concentration (mg/kg) } \\
\hline & & & \multirow{2}{*}{$\frac{\mathrm{Cd}}{4.05 \pm 0.58}$} & \multirow{2}{*}{$\frac{\mathrm{Cr}}{22.3 \pm 2.09}$} & \multirow{2}{*}{$\frac{\mathrm{Cu}}{647.63 \pm 75.86}$} & \multirow{2}{*}{$\frac{\mathrm{Fe}}{37729.53 \pm 4106.39}$} & \multirow{2}{*}{$\frac{\mathrm{Pb}}{112.76 \pm 19.75}$} \\
\hline \multirow{6}{*}{ Root } & \multirow{2}{*}{ CK } & & & & & & \\
\hline & & $+\mathrm{M}$ & $4.55 \pm 0.63$ & $17.91 \pm 2.73$ & $601.59 \pm 66.74$ & $28313.94 \pm 1734.90$ & $110.21 \pm 18.98$ \\
\hline & \multirow{2}{*}{$\mathrm{BC}$} & $-\mathrm{M}$ & $2.58 \pm 0.49$ & $19.26 \pm 1.59$ & $627.59 \pm 108.93$ & $34837.36 \pm 2841.34$ & $228.32 \pm 18.63$ \\
\hline & & $+\mathrm{M}$ & $3.11 \pm 0.50$ & $20.26 \pm 2.59$ & $656.07 \pm 144.83$ & $43098.66 \pm 6811.36$ & $212.32 \pm 17.98$ \\
\hline & \multirow{2}{*}{$\mathrm{Fe}-\mathrm{BC}$} & $-\mathrm{M}$ & $4.75 \pm 1.03$ & $24.02 \pm 3.70$ & $837.41 \pm 241.97$ & $39327.22 \pm 8011.74$ & $236.05 \pm 30.98$ \\
\hline & & $+\mathrm{M}$ & $4.02 \pm 0.44$ & $19.17 \pm 2.50$ & $1082.05 \pm 237.81$ & $49079.27 \pm 9232.02$ & $204.24 \pm 15.18$ \\
\hline \multirow{6}{*}{ Stem } & \multirow{2}{*}{ CK } & $-\mathrm{M}$ & $4.45 \pm 0.51$ & $25.46 \pm 4.10$ & $29.00 \pm 17.68$ & $940.20 \pm 183.40$ & $180.08 \pm 20.86$ \\
\hline & & $+\mathrm{M}$ & $3.46 \pm 0.60$ & $21.68 \pm 2.00$ & $25.16 \pm 2.11$ & $815.87 \pm 496.43$ & $145.83 \pm 9.45$ \\
\hline & \multirow{2}{*}{$\mathrm{BC}$} & $-\mathrm{M}$ & $1.78 \pm 0.45$ & $29.36 \pm 5.80$ & $16.00 \pm 4.50$ & $402.37 \pm 103.96$ & $129.35 \pm 24.35$ \\
\hline & & $+\mathrm{M}$ & $0.83 \pm 0.06$ & $28.35 \pm 5.02$ & $13.05 \pm 0.91$ & $369.91 \pm 17.40$ & $126.6 \pm 15.57$ \\
\hline & \multirow{2}{*}{$\mathrm{Fe}-\mathrm{BC}$} & $-\mathrm{M}$ & $2.90 \pm 0.46$ & $24.80 \pm 3.86$ & $22.46 \pm 9.62$ & $540.71 \pm 137.79$ & $151.66 \pm 22.8$ \\
\hline & & $+\mathrm{M}$ & $2.05 \pm 0.22$ & $24.30 \pm 2.80$ & $20.99 \pm 1.95$ & $457.59 \pm 123.01$ & $121.91 \pm 7.05$ \\
\hline \multirow{6}{*}{ Leaf } & \multirow{2}{*}{ CK } & $-\mathrm{M}$ & $2.51 \pm 0.44$ & $28.14 \pm 2.58$ & $39.15 \pm 11.97$ & $1187.16 \pm 102.33$ & $134.85 \pm 12.84$ \\
\hline & & $+\mathrm{M}$ & $2.29 \pm 1.05$ & $26.57 \pm 4.99$ & $33.70 \pm 4.64$ & $884.07 \pm 144.97$ & $108.29 \pm 24.83$ \\
\hline & \multirow{2}{*}{$\mathrm{BC}$} & $-\mathrm{M}$ & $2.50 \pm 0.30$ & $42.68 \pm 6.46$ & $32.41 \pm 2.22$ & $690.02 \pm 33.43$ & $193.83 \pm 21.43$ \\
\hline & & $+\mathrm{M}$ & $1.09 \pm 0.63$ & $31.52 \pm 3.04$ & $31.51 \pm 0.64$ & $568.1 \pm 32.26$ & $151.46 \pm 21.24$ \\
\hline & \multirow{2}{*}{$\mathrm{Fe}-\mathrm{BC}$} & $-\mathrm{M}$ & $1.94 \pm 0.52$ & $32.73 \pm 5.53$ & $30.29 \pm 7.32$ & $991.95 \pm 32.73$ & $138.42 \pm 20.36$ \\
\hline & & $+\mathrm{M}$ & $1.77 \pm 0.59$ & $30.38 \pm 3.95$ & $25.02 \pm 4.39$ & $882.52 \pm 55.09$ & $135.69 \pm 13.03$ \\
\hline
\end{tabular}


Table 3. Translocation factors (TF) calculated for the stems and leaves of Senna occidentalis.

\begin{tabular}{|c|c|c|c|c|c|c|c|c|c|c|c|}
\hline \multirow{3}{*}{$\begin{array}{l}\text { Biochar } \\
\text { addition }\end{array}$} & \multirow{3}{*}{$\begin{array}{l}\text { Inoculation } \\
\text { treatment }\end{array}$} & \multicolumn{10}{|c|}{$\mathrm{TF}$} \\
\hline & & \multicolumn{2}{|c|}{$\mathrm{Cd}$} & \multicolumn{2}{|c|}{$\mathrm{Cr}$} & \multicolumn{2}{|c|}{$\mathrm{Cu}$} & \multicolumn{2}{|c|}{$\mathrm{Fe}$} & \multicolumn{2}{|c|}{$\mathrm{Pb}$} \\
\hline & & Stem & Leaf & Stem & Leaf & Stem & Leaf & Stem & Leaf & Stem & Leaf \\
\hline \multirow{2}{*}{ CK } & $-\mathrm{M}$ & 1.008 & 0.557 & 1.047 & 1.158 & 0.041 & 0.055 & 0.023 & 0.029 & 1.465 & 1.097 \\
\hline & $+\mathrm{M}$ & 0.698 & 0.663 & 1.111 & 1.361 & 0.023 & 0.051 & 0.026 & 0.029 & 1.214 & 0.901 \\
\hline \multirow{2}{*}{$\mathrm{BC}$} & $-\mathrm{M}$ & 0.633 & 0.889 & 1.399 & 2.033 & 0.023 & 0.047 & 0.011 & 0.018 & 0.520 & 0.779 \\
\hline & $+\mathrm{M}$ & 0.245 & 0.322 & 1.284 & 1.427 & 0.018 & 0.044 & 0.008 & 0.012 & 0.547 & 0.654 \\
\hline \multirow{2}{*}{$\mathrm{Fe}-\mathrm{BC}$} & $-\mathrm{M}$ & 0.560 & 0.375 & 0.947 & 1.250 & 0.025 & 0.033 & 0.013 & 0.023 & 0.589 & 0.538 \\
\hline & $+\mathrm{M}$ & 0.468 & 0.404 & 1.163 & 1.454 & 0.018 & 0.021 & 0.009 & 0.016 & 0.548 & 0.610 \\
\hline
\end{tabular}

and $\mathrm{Fe}$ by $41.88 \%$ and $16.44 \%$, respectively, in the uninoculated samples. Under the condition of AMF inoculation, the decreasing amplitudes were $52.40 \%$ and $22.71 \%$ for $\mathrm{Cd}, 6.49 \%$ and $25.76 \%$ for $\mathrm{Cu}$ and $35.74 \%$ and $0.18 \%$ for $\mathrm{Fe}$, respectively. The effects of AMF inoculation on each element content in the leaves were consistent with those in the stems. When combined with biochar, AMF inoculation decreased the contents of all elements in the leaves.

The effects of the different treatments on the concentration of heavy metal elements in the stems and leaves differed and were related to the transfer of elements in the stems and leaves in the different treatments.

As indicated in Table 3, the effects of $\mathrm{BC}$ and $\mathrm{AMF}$ inoculation on the translocation factors (TF) of stems were generally consistent with those in the leaves. Regardless of AMF inoculation, standard BC and ironmodified $\mathrm{BC}$ both decreased the $\mathrm{TF}$ of $\mathrm{Cd}$ in the stems, and the $\mathrm{TF}$ of $\mathrm{Cu}, \mathrm{Fe}$ and $\mathrm{Pb}$ in the stems and leaves when compared to the control. While a single iron-modified $\mathrm{BC}$ treatment in the absence of AMF inoculation reduced the $\mathrm{TF}$ of $\mathrm{Cr}$ in the stems only compared to the control, both types of biochar increased the TF of $\mathrm{Cr}$ in both the stems and leaves. Under different biochar treatments, the effects of AMF inoculation on the TF of each element in the stems and leaves were different, but indicated a clear downward trend. The combination of AMF inoculation and standard BC slightly increased the $\mathrm{TF}$ of $\mathrm{Pb}$ in stems and decreased the TF of all the elements in the stems and leaves. The combination of iron-modified $\mathrm{BC}$ and $\mathrm{AMF}$ inoculation decreased the $\mathrm{TF}$ of $\mathrm{Cu}$ and $\mathrm{Fe}$ in both the stems and leaves, and the $\mathrm{TF}$ of $\mathrm{Cd}$ and $\mathrm{Pb}$ in the stems. The combinations of biochar and AMF inoculation were more conducive to the reduction in heavy metal transfer from the roots to the stems and leaves than a single treatment, though the elements corresponded differently to the different combinations. Compared to $\mathrm{CK}$ (lacking $\mathrm{BC}$ and $\mathrm{AMF}$ treatment), the combination of standard $\mathrm{BC}$ and $\mathrm{AMF}$ inoculation was more favorable for the reduction of the $\mathrm{TF}$ of $\mathrm{Cd}$ and $\mathrm{Fe}$ in the stems and leaves than a single treatment, while the combination of iron-modified BC and AMF inoculation was more favorable for reducing the $\mathrm{TF}$ of $\mathrm{Cu}$. The single treatment of iron-modified $\mathrm{BC}$ was most effective in reducing the $\mathrm{TF}$ of $\mathrm{Pb}$ and $\mathrm{Cr}$.

\section{Discussion}

In this study, AMF showed higher infection rates in the presence of heavy metal contamination, indicating that AMF possesses a certain level of tolerance toward heavy metals. The experimental results indicated that the effects of the 2 types of biochar on AMF infection differed greatly. Standard BC significantly increased the mycorrhizal infection rate, which is consistent with the results of Elmer et al. [15] and Han et al. [16]. This might be related to the fact that the biochar provided a favorable environment for harboring the pollution. An alternative explanation is that the biochar was able to adsorb the substances that are harmful to the mycorrhizal fungi [7, 17-18], effectively reducing the toxicity of several heavy metals to the mycorrhizal fungi. On the contrary, iron-modified $\mathrm{BC}$ decreased the mycorrhizal infection rate, indicating that iron-modified $\mathrm{BC}$ was not conducive to the survival of mycorrhizal fungi. The colonization of roots by AM fungi varied with the different types of biochar applied, which is consistent with the results of Han et al. [19], who found that the differences were associated with various processing conditions. In fact, the toxicity of some heavy metals to the mycorrhiza was enhanced by the addition of iron-modified biochar in this study (e.g., $\mathrm{Cu}$ and $\mathrm{Cr}$; Fig. 4).

Regardless of biochar application, mycorrhizal fungi were not found to influence soil $\mathrm{pH}$. However, the application of both biochars increased the soil $\mathrm{pH}$. This is related to the alkalinity of the biochar, and the result was consistent with most of the relevant research conclusions [20-22]. The increasing efficiency of the iron-modified $\mathrm{BC}$ on soil $\mathrm{pH}$ was lower than that of standard $\mathrm{BC}$. This can be explained by the fact that the tested substrates were acidic and the $\mathrm{Fe}^{2-}$ could release from iron-modified $\mathrm{BC}$ in acidic conditions and combine with $\mathrm{OH}^{-}$to reduce the soil $\mathrm{pH}$, offsetting the increase in $\mathrm{pH}$ caused by the biochar. 
Overall, AMF inoculation was associated with a significant growth-promoting effect on $S$. occidentalis (Fig. 3), which is consistent with several previous studies regarding the effect of AMF on growth stimulation of its host plants [2, 23]. Most studies indicated that the growth-promoting effect of AMF on plants was closely related to the improvement of plant $P$ (phosphorus) nutrition [24]. The extraradical hyphae are able to directly absorb inorganic P from the soil, while mycorrhizal secretions (such as phosphatase and organic acid) are able to mineralize organic $\mathrm{P}$, helping the host plant obtain the $\mathrm{P}$ required for growth [24]. In this experiment, when the 2 types of biochar were applied, the effects of AMF inoculation on $S$. occidentalis biomass and $\mathrm{P}$ concentration were more or less consistent, both indicating a significant positive effect (Fig. 3). This illustrated that the biochar provided shelter for mycorrhizae and promoted $\mathrm{P}$ use in $S$. occidentalis under heavy metal stress, positively influencing plant growth.

The effects of biochar and AMF on the $\mathrm{HCl}-$ extractable heavy metal content in the soil were significantly different across the different treatments $(P<0.05)$. Biochar and AMF had no significant effect on $\mathrm{Cd}$. $\mathrm{HCl}$-extractable $\mathrm{Fe}$ content was not significantly affected by the inoculation of AMF alone, but was increased by the combination of standard $\mathrm{BC}$ and $\mathrm{AMF}$ inoculation. Regardless of AMF inoculation, the $\mathrm{HCl}$ extractable $\mathrm{Fe}$ content was slightly increased by the application of iron-modified $\mathrm{BC}$, which was related to the exogenous iron brought by the iron-modified BC. Regardless of biochar application, AMF inoculation decreased the content of $\mathrm{HCl}$-extractable $\mathrm{Pb}$ in the soil, and the influence of AMF inoculation on $\mathrm{HCl}-$ extractable $\mathrm{Cr}$ and $\mathrm{Cu}$ was associated with the type of biochar. The $\mathrm{HCl}$-extractable $\mathrm{Cu}$ content in the soil was decreased by a single AMF inoculation treatment, but increased with the combination of standard $\mathrm{BC}$ and AMF inoculation, while $\mathrm{HCl}$-extractable $\mathrm{Cr}$ decreased. This difference might be related to the soil environment (such as pH and status of soil aggregates) as well as the characteristics of the heavy metals. When iron-modified $\mathrm{BC}$ was applied, AMF inoculation did not significantly affect $\mathrm{HCl}$-extractable $\mathrm{Cu}$ and $\mathrm{Cr}$ in the soil.

In the absence of AMF inoculation, a major difference in the effects of the 2 types of biochar on heavy metal content in roots was observed. The single treatment of standard $\mathrm{BC}$ increased $\mathrm{Pb}$ concentration in the roots but reduced the concentration of other elements $(\mathrm{Cd}, \mathrm{Cr}, \mathrm{Cu}$ and $\mathrm{Fe})$, which is consistent with several previous studies in which biochar reduced heavy metal absorption by the roots [25-27]. For instance, biochar application was previously found to reduce $\mathrm{Cd}$ concentrations in the shoots and roots of the common bent grass (Agrostis capillaris) and white lupen (Lupinus albus) [3]. Furthermore, sugarcane biochar reduced the uptake of $\mathrm{Pb}, \mathrm{Cd}$ and $\mathrm{Zn}$ in Canavalia ensiformis and Mucuna aterrima [28-29], while mischantus BC reduced $\mathrm{Cd}, \mathrm{Zn}$ and $\mathrm{Pb}$ concentrations in the shoots of rapeseed and ryegrass in polluted soil [30-31]. The increase in soil $\mathrm{pH}$ caused by the biochar reduced the bioavailable fraction of heavy metals and their uptake by plants. However, all element contents in the roots were increased by the application of iron-modified biochar. In acidic soil conditions, the $\mathrm{Fe}^{3-}$ content increased with the application of iron-modified $\mathrm{BC}$ and combined with $\mathrm{OH}^{-}$to form $\mathrm{Fe}(\mathrm{OH})_{3}$, which reduced the soil $\mathrm{pH}$ and increased the content of bio-available elements and their uptake. A single AMF inoculation treatment increased $\mathrm{Cd}$ concentration in roots but reduced the concentrations of other elements $(\mathrm{Cr}, \mathrm{Cu}, \mathrm{Fe}$ and $\mathrm{Pb})$. However, when standard BC was applied, AMF inoculation increased the contents of all elements in the roots except $\mathrm{Pb}$. The application of standard $\mathrm{BC}$ resulted in an increase in mycorrhizal infection, causing the AM fungi to fix heavy metals to the root or the cell wall and the plasma membrane of the external hyphae [32]. Similarly, Joner et al. [33] and Gonzalez-Chavez et al. [34] found that Glomus mosseae mycelium could increase the adsorption of $\mathrm{Cd}$ and $\mathrm{Cu}$. Furthermore, GonzalezChavez et al. [34] also suggested that the hydroxyl, carboxyl and amino acids with a negative valence in the hyphal cell wall could react with $\mathrm{Cu}^{2+}$. Similarly, the combination of iron-modified $\mathrm{BC}$ and $\mathrm{AMF}$ inoculation also greatly increased the $\mathrm{Cu}$ and $\mathrm{Fe}$ contents in roots in the present study.

In this experiment, the effect of biochar on the concentration of heavy metals in stems and leaves was not associated with AMF inoculation. The contents of all elements except $\mathrm{Cr}$ in the stems, and $\mathrm{Cd}, \mathrm{Cu}$ and $\mathrm{Fe}$ contents in leaves, were decreased by both types of biochar. A previous study found that rice biochar decreased the concentrations of $\mathrm{Cd}, \mathrm{Cu}, \mathrm{Pb}$ and $\mathrm{Zn}$ in the leaves of lettuce (Lactuca sativa) in a dosedependent manner [35]. Additionally, the effect of AMF inoculation on the heavy metal concentrations in stems and leaves was not associated with biochar application, and decreased the content of all elements in the stems and leaves. We discovered that the effects of biochar and AMF inoculation on plant heavy metal absorption from the soil was mainly influenced by the rhizosphere micro environment, changing the transfer of heavy metals from roots to shoots but not affecting the element transfer between stems and leaves. Compared with a single treatment, the infection rate in the combined treatment of biochar and AMF inoculation was higher and the element concentrations in the roots were increased, but the element concentrations and IF in the stems and leaves were decreased (Table 4). Under heavy metal contamination, excessive heavy metals could combine with polyphosphoric acid and organic acid in fungal tissues and mucus secretion in the fungal cell wall, etc. Several previous studies have had similar findings. For light heavy metal pollution, the inoculation of $G$. intraradices fungi increased the $\mathrm{Cu}$ and $\mathrm{Cd}$ concentration in the roots of clonal plant willow (Salix viminalis [5027]), while reducing their concentration in shoots [36]. According to Lins et al. [37], the $\mathrm{Cu}$ 
content in the shoots of Leucaena leucocephala with Glomus etunicatum inoculation was lower than the treatments lacking inoculation. The $\mathrm{Cu}, \mathrm{Zn}, \mathrm{Pb}$ and $\mathrm{Cd}$ contents in the roots of Sesbania rostrata, S. cannabina and Medicago sativa were significantly increased by AMF inoculation compared to the aboveground parts [38]. These results indicate that heavy metals could be immobilized and insulated by the AMF, which reduce the transfer of heavy metals to the aboveground parts and alleviate the physiological toxicity of heavy metals to plants. In this experiment, the combination of standard $\mathrm{BC}$ and $\mathrm{AMF}$ inoculation significantly increased $S$. occidentalis biomass, especially the aboveground stems and leaves, which was one of the reasons for the decrease in the heavy metal concentrations of aboveground parts. Therefore, the changes in heavy metal concentrations in plants may be attributed to a "growth dilution" effect [39-40]. A previous related study by Han et al. [19] and Qiao et al. [41] also indicated that biochar and AMF protected plants from heavy metal toxicity and promoted plant growth.

It is worth mentioning that the effect of AMF inoculation alone on root $\mathrm{Cd}$ content was different from the other elements and was related to the biological characteristics of $S$. occidentalis. The effects of biochar and AMF on the $\mathrm{HCl}$-extractable heavy metal contents were not entirely consistent with their content in roots, indicating that the heavy metal uptake by the roots was not only linked to the contents of bioavailable elements, but also to the root surface area and mycorrhizal infection rate, and so forth. Additionally, mycorrhizal infection and the surface area of the root cell wall influenced each other, affecting the root absorption of heavy metals. There were great differences in the effects of single biochar and AMF inoculation applications and their combination on the root heavy metal concentrations, which is related to the interaction of biochar and AMF. Further studies regarding the interaction of these mechanisms are required.

\section{Conclusions}

Mycorrhizal inoculation could promote growth in $S$. occidentalis. The promoting effects of the combination of biochar and AMF inoculation was higher than that of a single inoculation. The mycorrhizal infection efficiency of the apple branch $\mathrm{BC}$ treatment was higher than the iron-modified BC. Furthermore, the biochar combinations were able to increase the root heavy metal concentrations, especially iron-modified $\mathrm{BC}$, which increased the root $\mathrm{Cu}$ and $\mathrm{Fe}$ contents the most. A single application of iron-modified BC was also associated with the greatest increase in root $\mathrm{Cd}$, $\mathrm{Cr}$ and $\mathrm{Pb}$ contents. Thus a single application of ironmodified $\mathrm{BC}$ in combination with the mycorrhizal Glomus mosseae could stimulate the accumulation of heavy metals in plant roots, potentially realizing the goal of phytoremediation of heavy metal-contaminated soils. The 2 combinations both significantly decreased the heavy metal content in the shoots via the reduction of heavy metal translocation from the roots. The combination of AMF inoculation with standard $\mathrm{BC}$ was most beneficial for the decrease of $\mathrm{Cd}$ and $\mathrm{Cu}$ contents in the stems and leaves and promoted aboveground growth to the greatest extent. This combined treatment method can be used for decreasing heavy metal transfer to the shoots of $S$. occidentalis as well as reducing the risk of heavy metal pollution, especially in lightly polluted areas. Considering that $S$. occidentalis is endowed with heavy metal enrichment capacity and medicinal value, utilizing different combinations of biochar and AMF would allow $S$. occidentalis to contribute efficiently to both phytoremediation and medicinal applications. Considering the complex interaction between biochar and AMF on plant growth and mineral nutrition, further experiments are required to explore the optimal conditions for their combined application.

\section{Acknowledgements}

This research was supported by the National Key Research and Development Program of China(2017YFD0800900), the Doctoral Startup Research Project of China West Normal University(412666) and the Science and Technology Planning Project of Guangdong Province (2015A020209152 and 2016A030303050).

\section{Conflict of Interest}

The authors declare no conflict of interest.

\section{References}

1. SMITH S.E., READ D. Mycorrhizal Symbiosis[M]. San Diego: Academic Press, 148-158, 174-175, 403 182-186, 2008.

2. SARKAR A., ASAEDA T., WANG Q., RASHID M.H. Arbuscular mycorrhizal influences on growth, nutrient uptake, and use efficiency of Miscanthus sacchariflorus growing on nutrient-deficient river bank soil. Flora, 212, 46, 2015.

3. HOUBEN D., SONNET P., CORNELIS J. Biochar from Miscanthus: a potential silicon fertilizer. PLANT AND SOIL, 374 (1-2), 871, 2014.

4. PUGA A.P., ABREU C.A., MELO L.C.A., BEESLEY L. Biochar application to a contaminated soil reduces the availability and plant uptake of zinc, lead and cadmium. J Environ Manag, 159, 86, 2015.

5. JONES D.L., EDWARDS-JONES G., MURPHY D.V. Biochar mediated alterations in herbicide breakdown and leaching in soil. Soil Biology \& Biochemistry, 43, 804, 2011.

6. SINGH A., SINGH A.P., SINGH S.K., RAI S., KUMAR D. Impact of addition of biochar along with pgpr on rice yield, availability of nutrients and their uptake in alluvial 
soil. Journal of Pure \& Applied Microbiology, 10 (3), 2181, 2016.

7. WARNOCK D.D., LEHMANN J., KUYPER T.W., RILLIG M.C. Mycorrhizal responses to biochar in soil-concepts and mechanisms. PLANT AND SOIL, 300 (1-2), 9, 2007.

8. YAO Y., GAO B., INYANG M., ZIMMERMAN A.R., CAO X., PULLAMMANAPPALLIL P., YANG L. Biochar derived from anaerobically digested sugar beet tailings: Characterization and phosphate removal potential. Bioresource Technology, 102, 6273, 2011.

9. AGRAFIOTI E., KALDERIS D., DIAMADOPOULOS E. $\mathrm{Ca}$ and $\mathrm{Fe}$ modified biochars as adsorbents of arsenic and chromium in aqueous solutions. Journal of Environmental Management, 146, 444, 2014.

10. YADAV J.P., ARYA V., YADAV S., PANGHAL M., KUMAR S., DHANKHAR S. Cassia occidentalis L.: A review on its ethnobotany, phytochemical and pharmacological profile. Fitoterapia, 81, 223, 2010.

11. LOVE A., BANERJEE B.D., BABU C.R. Assessment of oxidative stress markers and concentrations of selected elements in the leaves of Cassia occidentalis growing wild on a coal fly ash basin. Environmental Monitoring and Assessment, 185, 6553, 2013.

12. PHILLIPS J.M., HAYMAN D.S. Improved procedures for clearing roots and staining parasitic and vesiculararbuscular mycorrhizal fungi for rapid assessment of infection [J].Transactions British Mycological Society, 55, $158,1970$.

13. BIERMANN B., LINDERMAN R.G. Quantifying vesicular-arbuscular mycorrhizae: a proposed method towards standardization. New Phytologist, 87 (1), 63, 1981.

14. State Environmental Protection Administration of China (SEPAC). The Technical Specification for Soil Environmental Monitoring; HJ/T 166-2004; Environmental Press of China: Beijing, China, 2004 [In Chinese].

15. ELMER W.H., PIGNATELLO J.J. Effect of Biochar Amendments on Mycorrhizal Associations and Fusarium Crown and Root Rot of Asparagus in Replant Soils[J]. Plant Disease, 95 (95), 960, 2011.

16. HAN Y., JR D.D.D., BOATENG A.A. Effect of Biochar Soil-Amendments on Allium porrum Growth and Arbuscular Mycorrhizal Fungus Colonization[J]. Journal of Plant Nutrition, 39 (11), 00-00, 2015.

17. JAAFAR N.M. Biochar as a Habitat for Arbuscular Mycorrhizal Fungi[M]/Mycorrhizal Fungi: Use in Sustainable Agriculture and Land Restoration. Springer Berlin Heidelberg, 297, 2014.

18. MEIER S., CURAQUEO G., KHAN N., BOLAN N., RILLING J., VIDAL C., FERNÁNDEZ N.,ACUÑA J., GONZÁLEZ M.E., CORNEJO P., BORIE F. Effects of biochar on copper immobilization and soil microbial communities in a metal-contaminated soil. Journal of Soils \& Sediments, 17 (5), 1237, 2015.

19. HAN Y.JR., DOUDS D.D., BOATENG A.A. Effect of biochar soil-amendments on Allium porrum growth and arbuscular mycorrhizal fungus colonization. JOURNAL OF PLANT NUTRITION, 39 (11), 1654, 2016.

20. FELLET G., MARCHIOL L., DELLE VEDOVE G., PERESSOTTI A. Application of biochar on mine tailings: Effects and perspectives for land reclamation. Chemosphere, 83, 1262, 2011.

21. SHI R.Y., HONG Z.N., LI J.Y., JIANG J., KAMRAN M.A., XU R.K., QIAN W. Peanut straw biochar increases the resistance of two ultisols derived from different parent materials to acidification: a mechanism study. Journal of Environmental Management, 210, 171, 2018.

22. DAI Z., WANG Y., MUHAMMAD N., YU X., XIAO K., MENG J., LIU X., XU J.,BROOKES P. The effects and mechanisms of soil acidity changes, following incorporation of biochars in three soils differing in initial pH. Soil Science Society of America Journal, 78 (5), 1606, 2014.

23. SCHNEIDER K.D., LYNCH D.H., DUNFIELD K., KHOSLA K., JANSA J., VORONEY R.P. Farm system management affects community structure of arbuscular mycorrhizal fungi. Applied Soil Ecology, 96, 192, 2015.

24. BAGYARAJ D.J., SHARMA M.P., MAITI D. Phosphorus nutrition of crops through arbuscular mycorrhizal fungi. Current Science, 108 (7), 1288, 2015.

25. LU K., YANG X., SHEN J., ROBINSON B., HUANG H., LIU D., BOLAN N., PEI J., WANG H. Effect of bamboo and rice straw biochars on the bioavailability of $\mathrm{Cd}, \mathrm{Cu}, \mathrm{Pb}$ and $\mathrm{Zn}$ to Sedum plumbizincicola. Agriculture Ecosystems \& Environment, 191, 124, 2014.

26. ZHU Q., WU J., WANG L., YANG G., ZHANG X. Effect of Biochar on Heavy Metal Speciation of Paddy Soil. Water Air and Soil Pollution, 226 (12, 1, 2015.

27. AL-WABEL M.I., USMAN A.R., EL-NAGGAR A.H., ALY A.A., IBRAHIM H.M., ELMAGHRABY S., ALOMRAN A. Conocarpus biochar as a soil amendment for reducing heavy metal availability and uptake by maize plants. Saudi J Biol Sci, 22 (4), 503, 2015.

28. HOUBEN D., SONNET P., CORNELIS J. Biochar from Miscanthus: a potential silicon fertilizer. PLANT AND SOIL, 374 (1-2), 871, 2014.

29. PUGA A.P., ABREU C.A., MELO L.C.A., PAZ-FERREIRO J., BEESLEY L. Cadmium, lead, and zinc mobility and plant uptake in a mine soil amended with sugarcane straw biochar. ENVIRONMENTAL SCIENCE AND POLLUTION RESEARCH, 22 (22), 17606, 2015.

30. HOUBEN D., EVRARD L., SONNET P. Beneficial effects of biochar application to contaminated soils on the bioavailability of $\mathrm{Cd}, \mathrm{Pb}$ and $\mathrm{Zn}$ and the biomass production of rapeseed (Brassica napus L.).Biomass Bioenerg, 57 (11), 196, 2013.

31. HOUBEN D., EVRARD L., SONNET P. Mobility, bioavailability and $\mathrm{pH}$-dependent leaching of cadmium, zinc and lead in a contaminated soil amended with biochar. CHEMOSPHERE, 92 (11), 1450, 2013.

32. REDON P., BEGUIRISTAIN T., LEYVAL C. Differential effects of AM fungal isolates on Medicago truncatula growth and metal uptake in a multimetallic $(\mathrm{Cd}, \mathrm{Zn}, \mathrm{Pb})$ contaminated agricultural soil. Mycorrhiza, 19 (3), 187, 2009.

33. JONER E.J., BRIONES R., LEYVAL C. Metal-binding capacity of arbuscular mycorrhizal mycelium, 226(2), 227, 2000.

34. GONZALEZ-CHAVEZ C., D'HAEN J., VANGRONSVELD J., DODD J.C. Copper sorption and accumulation by the extraradical mycelium of different Glomus spp. (arbuscular mycorrhizal fungi) isolated from the same polluted soil. Plant and Soil, 240, 287, 2002.

35. KIM H., KIM K., YOON J., YANG J.E., OK Y.S., OWENS G., KIM K. Effect of biochar on heavy metal immobilization and uptake by lettuce (Lactuca sativa L.) in agricultural soil. ENVIRONMENTAL EARTH SCIENCES, 74 (2), 1249, 2015.

36. BISSONNETTE L., ST-ARNAUD M., LABRECQUE M. Phytoextraction of heavy metals by two Salicaceae clones 
in symbiosis with arbuscular mycorrhizal fungi during the second year of a field trial. Plant and Soil, 332, 55, 2010.

37. LINS, C, CAVALCANTE U., SAMPAIO E., MESSIAS A.S., MAIA L.C. Growth of mycorrhized seedlings of Leucaena leucocephala (Lam.) de Wit. in a copper contaminated soil. Applied Soil Ecology, 31, 181, 2006.

38. LIN A., ZHANG X., WONG M., YE Z., LOU L., WANG Y., ZHU Y. Increase of multi-metal tolerance of three leguminous plants by arbuscular mycorrhizal fungi colonization. Environmental Geochemistry and Health, 29, 473, 2007.

39. CHEN B.D., ZHUY., DUAN J., XIAO X.Y., SMITH S.E. Effects of the arbuscular mycorrhizal fungus Glomus mosseae on growth and metal uptake by four plant species in copper mine tailings. Environmental Pollution, 147, 374, 2007.

40. CHEN B.D., XIAO X., ZHU Y., SMITH F.A., XIE Z.M., SMITH S.E. The arbuscular mycorrhizal fungus Glomus mosseae gives contradictory effects on phosphorus and arsenic acquisition by Medicago sativa Linn. Science of the Total Environment, 379, 226, 2007.

41. QIAO Y., CROWLEY D., WANG K., ZHANG H., LI $\mathrm{H}$. Effects of biochar and arbuscular mycorrhizae, on bioavailability of potentially toxic elements in an aged contaminated soil. Environmental Pollution, 206, 636, 2015. 
